\title{
Response of Malt Barley to Special Liquid Fertilizer (Rutter AA) in the Central Highlands of Ethiopia
}

\author{
*Girma Chala ${ }^{1} \quad$ Zeleke Obsa $^{1} \quad$ Emenu Jembere ${ }^{2}$ \\ 1.Holetta Agricultural Research Center, EIAR, P.O. Box. 31 \\ 2.Chemtex Trade Corp Company Country Coordinator
}

\begin{abstract}
The experiment was conducted at Welmera (Holeta \&Telecho) and Ejere (Cheri) districts during 2016 and 2017 main cropping season to evaluate response of yield and yield components of malt barley to special liquid fertilizer (Rutter AA) applications. The experiment was laid out in randomized complete block design with three replications. The treatments were different doses of Ruter AA with recommended NP, that is, $0,100 \% \mathrm{NP}, 100 \%$ $\mathrm{NP}+$ Ruter AA $4 \mathrm{~L} / \mathrm{ha}, 100 \% \mathrm{NP}+$ Ruter AA $2 \mathrm{~L} / \mathrm{ha}$ and 100\% NP + Ruter AA $6 \mathrm{~L} / \mathrm{ha}$ ). The results of this study indicated that the productivity of malt barley was significantly affected by different dose of Ruter AA applied. Applications of $100 \%$ NP fertilizer with Ruter AA liquid nutrient sources combination had a significant $(p<0.05)$ effect on grain yield and biomass yield of malt barley. In general application of liquid fertilizer (Rutter AA) indicates positive response on grain quality of malt barley. In conclusion, based on the findings of the experiment without application of liquid fertilizer but 100\% recommended NP fertilizer are economically optimum for malt barley production with acceptable grain quality in the Holeta, Cheri and Telecho study sites.
\end{abstract}

Keywords: Grain yield, Liquid fertilizer, Protein content

DOI: $10.7176 /$ JNSR/9-2-01

\section{INTRODUCTION}

Barley (Hordeum vulgare L.) is grown in diverse grain crop that could be used as forage as well as cover environments with the altitude range of 1500 and 3500 crop to improve soil fertility (Muluken Bantayehu, 2013). In Ethiopia, barely is the fourth most important crop after tef, maize and sorghum. In Ethiopia, barley production is highly concentrated in Oromia National Regional State with total area coverage of 454,662.78 hectares and total annual production of about 1.09 million tonnes, whereas the mean barley productivity was around 2.4 tonnes $\mathrm{ha}^{-1}$ in main cropping season (CSA, 2017). Barely is used in different forms such as bread, porridge, soup and roasted grain and straw is used for animal feed, thatching roofs and bedding. It is a fast growing, cool season, annual grain crop that could be used as forage as well as cover crop to improve soil fertility (Ghanbari et $a l, .2012)$. However, barely production in Ethiopia in general and in Oromia Region in particular is usually practiced with little or no external input mainly in the higher altitude or steep slopes, eroded lands or in moisture stress areas (Getachew, 2001). Malt barley is a high-opportunity crop, with great room for profitable expansion, particularly when connected with the country's commercial brewing and value-added industries (Berhane, 2011). Despite the importance of malt barley and its many useful characteristics, there are several factors affecting its production. The most important factors that reduce yield of barley in Ethiopia are poor soil fertility status, lack of special liquid fertilizer, poor crop management practices, and limited availability of improved varieties is among the most important constraints that threaten barley production in Ethiopia (Paul et al., 2011). Liquid Chemical fertilizer usage by malt barley producers in Ethiopia is too little yet. However, special liquid fertilizer (Rutter AA) is applied to improve yield and grain quality of malt barley. Therefore, the objective of this research was to evaluate response of malt barley to liquid fertilizer application which effects on yield components and grain quality.

\section{MATERIALS AND METHODS}

\section{Description of the Experimental Site}

The experiment was conducted during the 2016 and 2017 main cropping season at Welmera (Holeta \&Telecho) and Ejere (Cheri) districts . The study sites were located in the highlands of West Shewa zone between $09^{\circ} 00^{\prime} 3^{\prime \prime} \mathrm{N}$ latitude and $38^{\circ} 0^{\prime} 20^{\prime \prime} \mathrm{E}$ longitude and at an altitude of about 2400 meter above sea level (masl). The rainfall is bimodal with average annual rainfall of $1041.4 \mathrm{~mm}$, about $85 \%$ of which is received from June to September and the rest from January to May. The average minimum and maximum air temperature is 6.7 and $21.7{ }^{\circ} \mathrm{c}$ respectively with relative humidity of $58.7 \%$ ( HARC, 2016 and 2017). The environments are seasonally humid and the major soil type of the trial sites is Eutric Nitisols (FAO classification).

Experimental Treatments, Design and Procedure

Grain quality and yield response of malt barley to special liquid fertilizer (Rutter AA) experiment was conducted in major malt barley growing areas in west shoa zone for two years (2016-2017). The experiment was designed in RCBD with four replications and consisting of different doses of Ruter AA with recommended NP $(0,100 \%$ NP, 100\% NP + Ruter AA 4 L/ha, 100\% NP + Ruter AA 2 L/ha and 100\% NP + Ruter AA 6 L/ha). At least one 
weeding was done at tillering stage of barley even though farmers have no experience of weeding. The test crop was sown with row to row spacing of $20 \mathrm{~cm}$ comprising a total of 20 rows per plot in which a seed rate of $125 \mathrm{~kg}$ $\mathrm{kg} / \mathrm{ha}$ was maintained. Urea as $\mathrm{N}$ source was applied at the rate of $46 \mathrm{~kg} \mathrm{~N} \mathrm{~kg} / \mathrm{ha}$. Split application of nitrogen was used. Similarly, Rutter AA fertilizer (Table 2) were applied on 35 days after planting, and then the recommended doses for liquid fertilizers $(2,4$ and $6 \mathrm{~L} / \mathrm{ha})$ were applied more than six times with 20 days intervals. Phosphorus was applied to all plots uniformly at the rate of $46 \mathrm{~kg} \mathrm{P}_{2} \mathrm{O}_{5} \mathrm{~kg} / \mathrm{ha}$ as triple super phosphate (TSP) at planting.

Table 1: The five treatments used to examine the response of malt barley to liquid fertilizers.

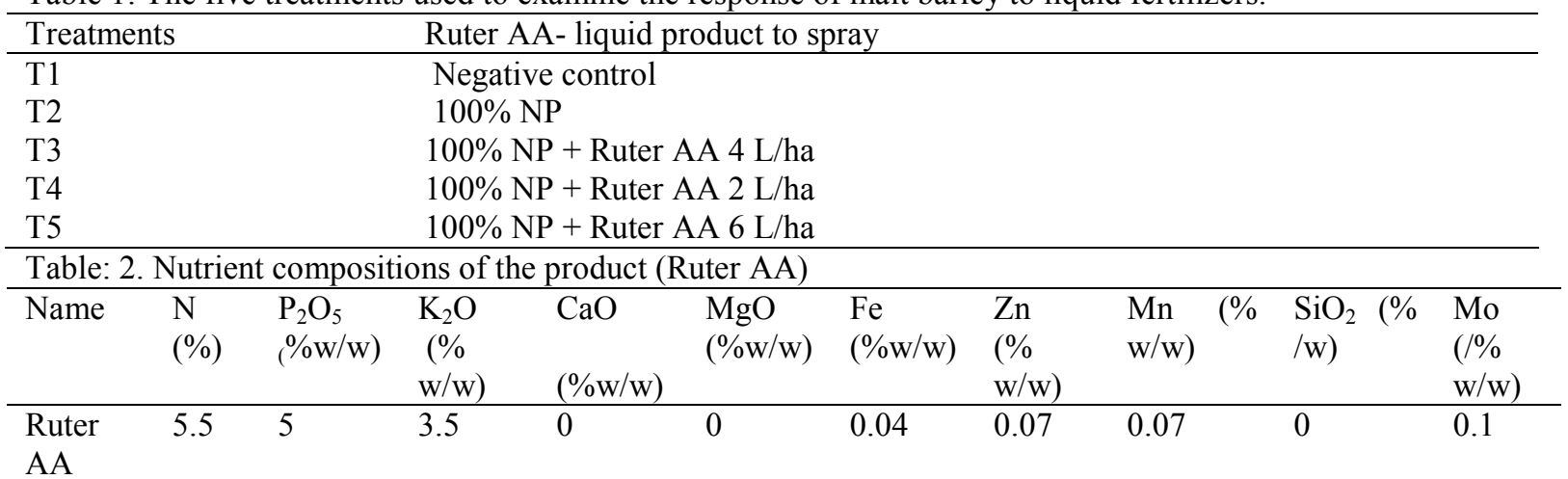

\section{Soil sampling and analysis}

Composite surface soil samples were collected from experimental fields $(0-20 \mathrm{~cm}$ depth) before treatment application. Similarly, samples were collected after harvest from each plot and then composited by replication to obtain one representative sample per treatment. Then, soil samples were analyzed to determine the soil $\mathrm{pH}, \mathrm{OC}$, total N, available P. Soil particle size distribution/ texture/ was determined by Bouyoucos hydrometer method (Bouyoucos, 1962). The $\mathrm{pH}$ of the soil was measured from suspension of 1:2.5 (weight/ volume) soil to water ratio (Page, 1982). Soil OC was determined by wet oxidation method as described by Walkely and Black (1934). Total nitrogen was determined using Kjeldahl method as described by Jackson (1967) and available phosphorus was determined by the Bray II method (Bray and Kurtz, 1945). Cation exchange capacity (CEC) was measured after saturating the soil with $1 \mathrm{~N}$ ammonium acetate (NH4OAC) and displacing the ammonium ion with $1 \mathrm{~N}$ NaOAC (Chapman, 1965)

Data collection and analysis

All agronomic data were taken from the net harvested plot areas. Spacing between replications and between plots was 1 and $0.5 \mathrm{~m}$, respectively. Plant height at maturity $(\mathrm{cm})$, spike length $(\mathrm{cm})$, biomass yield and grain yield were collected as growth and yield parameters of malt barley. Hectoliter weight, grain protein content, Moisture Contents and germination energy were collected as malt quality parameters of the study. Grain yield was adjusted to a moisture content of $12.5 \%$ before proceeding to statistical analysis.

The analysis of variance (ANOVA) was carried out for growth and yield parameters of the study following statistical procedures appropriate for the experimental design using SAS statistical Analysis System (SAS, 2004). Whenever treatment effects were significant at 0.01 or 0.05 probability level and the means were separated by using the least significant difference (LSD) procedures at 0.05 probability level of significance. A grain sample was taken at all sites of each location for determination of grain protein content. The grain $\mathrm{N}$ content was analyzed by the Kjeldahl method (Minale et al., 2011) and the result was multiplied by 5.85 to obtain the grain protein content.

\section{Economic analysis}

Partial budgeting analysis was widely used to better understand the economic implication of adopting new technologies by smallholders (Assefa, 2015). The mean grain yield data were reduced by $10 \%$ to adjust the yield to the farmers' management conditions and subjected to partial budget analysis (CIMMYT, 1988). The cost of fertilizer was considered as a variable cost for the economic analysis. The cost varied for each treatment and treatments were ranked in order of ascending variable cost. Dominance analysis was used to eliminate those treatments which cost more, but which produced a lower net benefit, than the next lowest-cost treatment. The marginal rate of return (MRR) was calculated for each non dominated treatment and a minimum acceptable MRR of 100\% was assumed (CIMMYT, 1988) as showed in (Table 6, 7 and 8). Two years average market grain price of malt barley (12 birr $/ \mathrm{kg}$ ), farm-gate price of $\mathrm{N}$ and $\mathrm{P}$ fertilizers (12 and $15 \mathrm{birr} / \mathrm{kg}$ ) respectively and price of Rutter AA liquid fertilizer 40 birr/Letter were used.

\section{RESULTS AND DISCUSSION}


were presented in Table 3. The soil particle size distribution of the study sites were clay (72\%), silt (18.25\%) and sand $(9.75 \%)$ for Holeta, while for Cheri clay $(73.4 \%)$, silt $(19.65 \%)$ and sand $(6.55 \%)$, and textually dominated by clay soil for all sites. For Holeta the average soil $\mathrm{pH}\left(\mathrm{H}_{2} \mathrm{O}\right)$ after harvesting was 5.67 which is moderately acidic in its reaction; for Cheri the average $\mathrm{pH}\left(\mathrm{H}_{2} \mathrm{O}\right)$ of the experimental field soil after harvesting was 4.66 showing strong acidity in its reaction.

Table: 3. The Rutter AA liquid fertilizer application on soil chemical properties analyzed samples after harvest of the crops

\begin{tabular}{|c|c|c|c|c|c|c|c|c|c|c|}
\hline \multirow[b]{2}{*}{$\begin{array}{c}\text { Loc } \\
\text { atio } \\
n\end{array}$} & \multirow[b]{2}{*}{$\mathrm{N} \mathrm{kg/ha}$} & \multicolumn{4}{|c|}{ Particle size Distribution } & \multicolumn{5}{|c|}{ Chemical Properties } \\
\hline & & $\begin{array}{l}\text { Clay } \\
(\%)\end{array}$ & $\begin{array}{l}\text { Silt } \\
(\%)\end{array}$ & $\begin{array}{l}\text { Sand } \\
(\%)\end{array}$ & $\begin{array}{l}\text { Textural } \\
\text { class }\end{array}$ & $\begin{array}{c}\mathrm{pH} \\
\left(\mathrm{H}_{2} \mathrm{O}\right)\end{array}$ & $\begin{array}{l}\mathrm{TN} \\
(\%)\end{array}$ & $\begin{array}{c}\mathrm{CEC} \\
\mathrm{Cmol}_{\mathrm{c}} \mathrm{kg}^{-}\end{array}$ & $\begin{array}{l}\mathrm{OC} \\
(\%)\end{array}$ & $\begin{array}{l}\text { Av.P } \\
(\mathrm{ppm})\end{array}$ \\
\hline \multirow{5}{*}{$\frac{\pi}{\frac{\pi}{0}}$} & 0 & 72.50 & 21.25 & 6.25 & Clay & 5.70 & 0.12 & 27.1 & 1.82 & 13.24 \\
\hline & RNP $100 \%$ & 72.5 & 16.25 & 11.25 & Clay & 5.75 & 0.13 & 24.64 & 1.82 & 12.32 \\
\hline & $\begin{array}{l}100 \% \text { RNP + } 4 \\
\text { L/ha }\end{array}$ & 70 & 18.75 & 11.25 & Clay & 5.68 & 0.14 & 29.3 & 1.78 & 11.79 \\
\hline & $\begin{array}{c}100 \% \text { RNP }+2 \\
\text { L/ha }\end{array}$ & 72.5 & 16.25 & 11.25 & Clay & 5.60 & 0.14 & 30.32 & 1.74 & 12.11 \\
\hline & $\begin{array}{l}100 \% \text { RNP + } 6 \\
\text { L/ha }\end{array}$ & 72.5 & 18.75 & 8.75 & Clay & 5.62 & 0.24 & 30.92 & 1.70 & 12.52 \\
\hline \multirow{5}{*}{ : } & 0 & 73.0 & 21.25 & 3.75 & Clay & 4.65 & 0.1 & 26.72 & 1.74 & 11.29 \\
\hline & $100 \%$ RNP & 73.5 & 18.75 & 7.75 & Clay & 4.63 & 0.14 & 26.92 & 1.90 & 10.79 \\
\hline & $\begin{array}{l}100 \% \mathrm{RNP}+4 \\
\mathrm{~L} / \mathrm{ha}\end{array}$ & 72.5 & 21.25 & 6.25 & Clay & 4.66 & 0.15 & 28.96 & 1.78 & 11.78 \\
\hline & $\begin{array}{c}100 \% \mathrm{RNP}+2 \\
\mathrm{~L} / \mathrm{ha}\end{array}$ & 73.5 & 18.25 & 8.25 & Clay & 4.75 & 0.16 & 28.7 & 1.74 & 12.13 \\
\hline & $\begin{array}{l}100 \% \text { RNP + } 6 \\
\text { L/ha }\end{array}$ & 74.5 & 18.75 & 6.75 & Clay & 4.62 & 0.24 & 30.92 & 1.70 & 12.52 \\
\hline
\end{tabular}

$\mathrm{CL}=$ Clay, $\mathrm{CEC}=$ Cation exchange capacity, $\mathrm{OC}=$ Organic carbon, $\mathrm{TN}=$ Total nitrogen, Av. $\mathrm{P}=$ Available phosphorus. $\mathrm{RNP}=$ recommended NP

The total $\mathrm{N}$ contents of soils after harvest were $0.154 \%$ (Holeta) and $0.158 \%$ (Cheri), respectively. Organic carbon content of the soil after harvesting was $1.76 \%$ for Holeta and $1.77 \%$ for Cheri which means they are classified under medium level for both sites. The CEC of the study area after harvesting was $28.46 \mathrm{cmolc} \mathrm{kg}^{-1}$, $28.44 \mathrm{cmolc} \mathrm{kg}^{-1}$, respectively for Holeta and Cheri. The available phosphorus content of the study area for Holeta and Cheri after harvesting was 12.39 ppm, 11.7 ppm, respectively.

Response of malt barley to Ruter AA liquid fertilizer

The effect of Ruter AA liquid fertilizer on grain and biomass yield, pooled over two cropping seasons, are presented below in table 4 . The study indicated that productivity of malt barley was significantly affected by different treatments applied. Thus, applications of RNP and Ruter AA liquid nutrient sources in combination had a significant $(\mathrm{p}<0.05)$ effect on grain and biomass yield of malt barley. When compared with standard check, application of $100 \%$ RNP with $6 \mathrm{~L} /$ ha Ruter AA increased malt barley grain yield by $8.6,8.9$ and $17.6 \%$ at Holeta, Cheri and Telecho, respectively. The biomass yield of malt barley was also significantly influenced by supplemental application of Ruter AA fertilizer, particularly at Cheri and Telecho sites. The application of $100 \%$ RNP with $4 \mathrm{~L} /$ ha Ruter AA increased biomass yield by $21.2 \%$ at Holeta. Similarly application of $100 \%$ RNP with $6 \mathrm{~L} /$ ha Ruter AA increased biomass yield by $7.4 \%$ but at Telecho application of recommended rates of NP with $6 \mathrm{~L} /$ ha Ruter AA increased biomass yield by $16.9 \%$ yield advantage when compared with standard check control.

Table: 4. over years (2016 and 2017) mean response of malt barley grain and biomass yield to Ruter AA liquid fertilizer

\begin{tabular}{lllllll}
\hline \multirow{2}{*}{ Treatments } & \multicolumn{3}{c}{ Grain yield (kg/ha) } & \multicolumn{3}{c}{ Biomass yield (kg/ha) } \\
\cline { 2 - 7 } & $\begin{array}{l}\text { Site1 } \\
(\text { Holeta })\end{array}$ & $\begin{array}{l}\text { Site2 } \\
(\text { Cheri) }\end{array}$ & $\begin{array}{l}\text { Site3 } \\
(\text { Telecho) }\end{array}$ & $\begin{array}{l}\text { Site1 } \\
\text { (Holeta) }\end{array}$ & $\begin{array}{l}\text { Site2 } \\
(\text { Cheri) }\end{array}$ & $\begin{array}{l}\text { Site3 } \\
(\text { Telecho })\end{array}$ \\
\hline Negative control & $1779.0^{\mathrm{b}}$ & $1432.1^{\mathrm{b}}$ & $1243.9^{\mathrm{b}}$ & 7227.5 & $7197.8^{\mathrm{b}}$ & $3873.3^{\mathrm{b}}$ \\
$100 \%$ RNP & $2679.4^{\mathrm{a}}$ & $2511.7^{\mathrm{a}}$ & $2228.6^{\mathrm{a}}$ & 8361.1 & $9440.8^{\mathrm{a}}$ & $6789.7^{\mathrm{a}}$ \\
$100 \%$ RNP +Ruter AA 4 L/ha & $2878.6^{\mathrm{a}}$ & $2613.6^{\mathrm{a}}$ & $2060.75^{\mathrm{a}}$ & 8861.1 & $9944.5^{\mathrm{a}}$ & $6102.5^{\mathrm{a}}$ \\
$100 \%$ RNP +Ruter AA 2 L/ha & $2647.2^{\mathrm{a}}$ & $2548.6^{\mathrm{a}}$ & $2017.6^{\mathrm{a}}$ & 7312.5 & $9444.5^{\mathrm{a}}$ & $5524.6^{\mathrm{a}}$ \\
$100 \%$ RNP +Ruter AA 6 L/ha & $2768.5^{\mathrm{a}}$ & $2533.9^{\mathrm{a}}$ & $2318.3^{\mathrm{a}}$ & 9216.9 & $9852.4^{\mathrm{a}}$ & $6644.1^{\mathrm{a}}$ \\
\hline LSD (5\%) & 417.7 & 704.9 & 613.7 & Ns & 864.6 & 2417.3 \\
CV $(\%)$ & 11.2 & 19.7 & 20.2 & 7.9 & 19.3 & 19.5 \\
\hline
\end{tabular}




\section{Quality Parameters of malt barley}

Hectoliter weight had a linear and positive response to Ruter AA liquid fertilizer. The highest $\left(68.52 \mathrm{~kg} \mathrm{hl}^{-1}\right)$ hectoliter weight was recorded from the highest applied 100\% RNP + Ruter AA $6 \mathrm{~L} / \mathrm{ha}$ and the lowest $(66.79 \mathrm{~kg}$ $\mathrm{hl}^{-1}$ ) hectoliter weight was recorded from negative control treatment (Table 5). Low values of HLW indicate poor grain filling. The acceptable test weights (hectoliter weight) for barley are in the range $\mathbf{6 6 . 1}-\mathbf{7 2 . 8 k g ~ h ~ ^ { - 1 }}$ (Rick et al., 2014). Similarly, the highest grain protein content $(13.86 \%)$ was recorded on $100 \%$ RNP + Ruter AA 6 L/ha and the lowest grain protein $(10.58 \%)$ from negative control treatment and the highest germination energy $(96.14 \%)$ value was obtained from negative control treatments, while the lowest $(94.24 \%)$ was observed at $100 \%$ RNP + Ruter AA 6 L/ha .On the other hand, as protein content of malt barley increases, as Rutter AA fertilizer was increased. Similar research findings with many authors (McKenzie et al., 2008; Daniel ,2010) reported that with low available nutrients in the soil, malt barley responds well to applied fertilizer, showing increases in both yield and protein content(Johnston et al., 2007). Regards to moisture levels need to be low enough to inactivate the enzymes involved in seed germination as well as to prevent heat damage and the growth of disease microorganisms (EQSA, 2006). Fox et al. (2003) reported that the maximum reasonable industrial specification of malt barley moisture content for safe storage is $12.5 \%$, whereas, the EBC standard, a moisture content of 12 $13.5 \%$ is accepted.

Table: 5. Effect of Ruter AA liquid fertilizer on malt barley quality parameter

\begin{tabular}{lcccc}
\hline Applied N rate (kg/ha) & $\begin{array}{c}\text { Hectoliter } \\
\text { weight }(\mathrm{kg} / \mathrm{hl})\end{array}$ & $\begin{array}{c}\text { Grain protein } \\
\text { content }(\%)\end{array}$ & $\begin{array}{c}\text { Germination } \\
\text { energy (\%) }\end{array}$ & $\begin{array}{c}\text { Moisture } \\
\text { Contents (\%) }\end{array}$ \\
\hline Negative control & 63.79 & 10.58 & 96.14 & 12.56 \\
100\% RNP & 66.74 & 11.23 & 95.66 & 12.62 \\
100\% RNP + Ruter AA 4 L/ha & 68.22 & 12.28 & 94.72 & 12.48 \\
100\% RNP + Ruter AA 2 L/ha & 67.46 & 11.46 & 95.06 & 12.65 \\
100\% RNP + Ruter AA 6 L/ha & 68.52 & 13.84 & 94.24 & 12.58 \\
\hline
\end{tabular}

\section{Economic analysis}

The results of the partial budget analysis (Tables 6, 7 and 8) revealed that the economically optimum yield and acceptable grain quality was varies with application dose of liquid fertilizer (Rutter AA). The economic analysis further indicates that, the highest marginal rate of the return (MRR) were recorded from the application of $100 \%$ Recommended NP plus 4L/ha Rutter AA at Holeta(Table 6 ) and Cheri site (Table 7), but 6 L/ha Rutter AA liquid fertilizer at Telecho study sites. From this findings, application of different dose of liquid fertilizer (Rutter AA ) were not economically feasible with combination of $100 \%$ recommended NP for malt barley production with acceptable grain quality in the Holeta, Cheri and Telecho study sites.

Table 6: Partial budget and dominance analyses of Rutter AA fertilizer on malt barley at Holeta

\begin{tabular}{|c|c|c|c|c|c|c|}
\hline Treatments & $\begin{array}{l}\text { Average } \\
\text { yield } \\
(\mathrm{kg} / \mathrm{ha})\end{array}$ & $\begin{array}{l}\text { Adjusted yield-10\% } \\
(\mathrm{kg} / \mathrm{ha})\end{array}$ & $\begin{array}{l}\text { Net benefit } \\
\text { (birr/ha) }\end{array}$ & $\begin{array}{l}\text { Total } \\
\text { cost }\end{array}$ & variable & $\begin{array}{l}\text { MRR } \\
(\%)\end{array}$ \\
\hline Negative & 2293.1 & 2063.79 & 24765.48 & & 0 & \\
\hline $100 \%$ RNP & 3262.5 & 2936.3 & 32085 & & 3150 & 232.37 \\
\hline $\begin{array}{l}100 \% \text { RNP + Rutter AA } \\
2 \mathrm{~L} / \mathrm{ha}\end{array}$ & 3268.5 & 2941.7 & 31729.8 & & 3610 & $\mathrm{D}$ \\
\hline $\begin{array}{l}100 \% \text { RNP + Rutter AA } \\
4 \text { L/ha }\end{array}$ & 3510.3 & 3159.3 & 34301.2 & & 3570 & 6428.6 \\
\hline $\begin{array}{l}100 \% \text { RNP + Rutter AA } \\
6 \mathrm{~L} / \mathrm{ha}\end{array}$ & 3456 & 3110.4 & 33634.8 & & 3690 & $\mathrm{D}$ \\
\hline
\end{tabular}

Table 7: Partial budget and dominance analyses of Rutter AA fertilizers trial on malt barley at Cheri-sites

\begin{tabular}{|c|c|c|c|c|c|c|}
\hline Treatments & $\begin{array}{l}\text { Average } \\
\text { yield } \\
(\mathrm{kg} / \mathrm{ha})\end{array}$ & $\begin{array}{l}\text { Adjusted } \\
\text { yield-10\% } \\
(\mathrm{kg} / \mathrm{ha})\end{array}$ & $\begin{array}{l}\text { Gross } \\
\text { benefits } \\
\text { (birr/ha) }\end{array}$ & $\begin{array}{l}\text { Total } \\
\text { variable } \\
\text { cost }\end{array}$ & $\begin{array}{l}\text { Net benefit } \\
\text { (birr/ha) }\end{array}$ & MRR (\%) \\
\hline Negative & 1729.4 & 1556.46 & 18677.5 & 0 & 18677.5 & \\
\hline $100 \%$ RNP & 2881.7 & 2593.53 & 31122.4 & 3150 & 27972.4 & 295.1 \\
\hline $\begin{array}{l}100 \% \text { RNP + Ruter AA } \\
2 \mathrm{~L} / \mathrm{ha}\end{array}$ & 2941.8 & 2647.62 & 31771.4 & 3610 & 28161.4 & 41.1 \\
\hline $\begin{array}{l}100 \% \text { RNP + Ruter AA } \\
4 \text { L/ha }\end{array}$ & 2577.4 & 2319.66 & 27835.9 & 3570 & 24265.9 & 9738.8 \\
\hline $\begin{array}{l}100 \% \text { RNP + Ruter AA } \\
6 \mathrm{~L} / \mathrm{ha}\end{array}$ & 2789.7 & 2510.73 & 30128.8 & 3690 & 26438.8 & 1810.7 \\
\hline
\end{tabular}


Table 8: Partial budget and dominance analyses of Rutter AA fertilizers trial on malt barley at Telecho

\begin{tabular}{|c|c|c|c|c|c|c|}
\hline Treatments & $\begin{array}{l}\text { Average } \\
\text { yield } \\
(\mathrm{kg} / \mathrm{ha})\end{array}$ & $\begin{array}{l}\text { Adjusted } \\
\text { yield-10\% } \\
(\mathrm{kg} / \mathrm{ha})\end{array}$ & $\begin{array}{l}\text { Gross } \\
\text { benefits } \\
\text { (birr/ha) }\end{array}$ & $\begin{array}{l}\text { Total } \\
\text { variable } \\
\text { cost }\end{array}$ & $\begin{array}{l}\text { Net benefit } \\
\text { (birr/ha) }\end{array}$ & $\begin{array}{l}\text { MRR } \\
(\%)\end{array}$ \\
\hline Negative & 1480.7 & 1332.63 & 15991.56 & & 15991.56 & \\
\hline $100 \%$ RNP & 2473.6 & 2226.24 & 26715 & 3150 & 23564.9 & 240.4 \\
\hline $\begin{array}{l}100 \% \text { RNP }+ \text { Ruter } \\
\text { AA } 2 \text { L/ha }\end{array}$ & 2196.3 & 1982.37 & 23788 & 3570 & 20218.4 & D \\
\hline $\begin{array}{l}100 \% \text { RNP + Ruter } \\
\text { AA } 4 \mathrm{~L} / \mathrm{ha}\end{array}$ & 2012.6 & 1811.34 & 21736 & 3610 & 18126.1 & D \\
\hline $\begin{array}{l}100 \% \text { RNP }+ \text { Ruter } \\
\text { AA } 6 \mathrm{~L} / \mathrm{ha}\end{array}$ & 2639.3 & 2375.37 & 28504 & 3690 & 24814.4 & 8360.5 \\
\hline
\end{tabular}

\section{CONCLUSION AND RECOMMENDATION}

Ethiopia has a high potential for barley production and field experiment was conducted at Welmera (Holeta \&Telecho) and Ejere (Cheri) districts during 2016-2017 main cropping seasons. Barley production is heavily dependent on available nutrient in the soil and other condition for plant growth. Information on crops response to nutrients and improved variety is crucial to come up with profitable and sustainable crop production. The aim of this study was to increase yield and yield components of malt barley production using appropriate nutrients and agronomic practices at Welmera (Holeta \&Telecho) and Ejere (Cheri) districts. Application of different rates of Rutter AA liquid fertilizers was not significantly affected grain and biomass yield when compared to $100 \%$ recommended NP treatment, but there was significance difference observed on grain and biomass yield when compared to with negative control treatment. With regard to the protein content of the treatments, all the Ruter AA doses slightly increased the protein content of the malt barely. However, the protein content of the malt barely is considered to be superior when it is lower than $12 \%$, recommended nitrogen and phosphorus fertilizers being the best.

According to the Ethiopian standard authority and Asella malt factory (AMF), the protein level of the raw barley quality standard for malt should be between 9-12\% (EQSA, 2006). The results of the current study showed that grain protein content within the acceptable range, except (100\% RNP + Rutter AA 6L/ha) (Table 10). So, applying Rutter AA liquid fertilizer product in addition to the recommended fertilizers doesn't improve both the yield and protein quality of malt at all locations. Economic analysis showed that the highest marginal rate of return was obtained from application of $100 \%$ Recommended NP plus Rutter AA 4L/ha fertilizer at Holeta and Cheri but at Telecho the highest marginal rate of return was obtained from application of $100 \%$ recommended NP plus Rutter AA 6L/ha fertilizer.

\section{ACKNOWLEDGMENTS}

We would like to thank the Chemtex trade corp Company for the provision of the products as well as financial support and would like to express their appreciation to Inorganic soil fertility program team of HARC for their technical assistance during the execution of the experiments under field condition. Appreciation is also due for the services of the analytical soil and food science laboratory of Holeta Agricultural Research Centre.

\section{REFERENCES}

Assefa Workineh. 2015. Response of barley to integrated cattle manure and mineral fertilizer application in the Vertisol areas of South Tigray, Ethiopia. Journal of Plant Sciences, 3(2): 71-76.

Bouyoucos, J. 1962. Hydrometer method improved for making particle size analysis of soil. Agronomy Journal, 54: 464-465.

Bray R.H., and Kurz L. T. 1945. Determination of total, organic and available forms of phosphorous in soil. Soil science Journal, 59: 39-45.

Central statistical agency agricultural sample survey. 2017. Report on area and production of major crops (private peasant holdings, Meher season). Volume I, Statistical bulletin, Addis Ababa, Ethiopia.

Chapman, H. D. 1965. Cation exchange capacity by ammonium saturation. 9: Inc 891-901. Black, C.A., L.E. Ensminger and Clark F.E. (Eds.). Method of soil analysis. American Society of Agronomy, Madison Wisconsin, USA.

CIMMYT. 1988. From Agronomic Data to Farmer Recommendations. An Economics Training Manual. Completely Revised Edition. CIMMYT, Mexico, D.F.

Daniel Tadesse .2010. Genetic variation of malt barley genotypes in their yield and $N$ use efficiency. MSc Thesis, Bahir Dar University, Ethiopia.

EQSA (Ethiopia Quality Standards Authority). 2006. Malting Barley Specification. Addis Ababa, Ethiopia. 
Ethiopia, 11-14 February, 1986.

Food and agriculture organization (FAO), 2016. Global production of barley and soil fertility.www. fao.org. Retrieved 18 June2016.

Fox, G.P., Panozzo J.F., Li, C.D., Lance, R.C.M., Inkerman, P.A. and Henry, R.J. 2003. Molecular basis of barley quality. Australian Journal of Agricultural Research, 54: 1081-1101.

Getachew Agegnehu, Amare Ghizaw and Woldeyesus Sinebo. 2008. Yield potential and land-use efficiency of wheat and faba bean mixed intercropping. Agronomy for Sustainable Development, Springer Verlag/EDP Sciences/INRA, 2008, 28 (2), pp.257-263.

Ghanbari, A., M. Babaeian, Y. Esmaeilian, A. Tavassoliand and A. Asgharzade, 2012. The effect of cattle manure and chemical fertilizer on yield and yield component of barley (Hordeum vulgare L.). African Journal of Agricultural Res., 7(3): 504-508.

HARC (Holetta Agricultural Research Center). 2016 / 2017. Agrometeorological data annual progress Report, Holeta, Ethiopia

Jackson, M. L. 1962. Soil chemical analysis. New Delhi, Prentice Hall of India Pvt. Ltd, 498

Johnston A, Murrel S, and Grant C. 2007. Nitrogen fertilizer management of malting barley: Impacts of crop and fertilizer nitrogen prices, 21-24.

McKenzie RH, Middleton AB, and Bremer E. 2008. Fertilization, seeding date and seeding rate for malting barley yield and quality in southern Alberta. Canada Journal of Plant Sciences, 85: 603-614

Minale Liben, Alemayehu Assefa and Tilahun Tadesse, 2011. Grain yield and malting quality of barley in relation to nitrogen application at mid- and high altitude in Northwest Ethiopia. Journal of Science and Development, 1(1): 75-88.

Muluken Bantayehu, 2013. Study on malting barley genotypes under diverse Agroecologies of north western Ethiopia. African Journal of Plant Science, 7(11): 548-557.

Page, A.L. 1982. Methods of soil analysis. Part II: Chemical and microbiological properties.

Rick Graham, Ian Menz, Nick Moody and Neroli Graham, 2014. Western Australian malting barley varietal recommendations. Date: 11 Feb 2014.

SAS. 2004. SAS/STAT User's Guide, Version 9.0. SAS institute Inc., Cary, and NC.USA.

Walkley, A. and Black I.A.1934. Estimation of soil organic carbon by the chromic acid titration method. Soil Science, 37: 29-38. 